\title{
Effects on the Female Reproductive System of Air Pollution Produced by the Use of Wood Combustion for Residential Heating: Challenges and Perspectives of Morphological Studies
}

\author{
Efectos Sobre el Sistema Reproductivo Femenino de la Contaminación del Aire Producido por el \\ Uso de la Combustión de Madera para Calefacción Residencial: Retos y Perspectivas de los \\ Estudios Morfológicos
}

Paulo Salinas

SALINAS, P. Effects on the female reproductive system of air pollution produced by the use of wood combustion for residential heating: Challenges and perspectives of morphological studies. Int. J. Morphol., 36(2):623-628, 2018.

SUMMARY: Previous studies have shown that air pollution affects cardio-respiratory function, but its role regarding reproductive processes is unknown. There are few experimental background studies on its effects on the morpho-function in the reproductive system. The use of wood combustion for residential heating (WCRH) in the cities of south-central Chile has increased significantly. As a result, it has become a source of significant emissions of particulate matter suspended (PM) in the air. The possible association between exposure to PM and reproductive problems has been suggested only on the basis of epidemiological studies, most of them carried out in environments where the main source of PM emission is the combustion of oil by motorized vehicles and industries, ignoring the effects produced by the smoke of WCRH. For example, in the city of Temuco-Padre Las Casas, Chile, $93 \%$ of PM emissions correspond to WCRH smoke, thus being considered an urban area with a single PM emission source and the factors that contribute to this type of contamination are reasonably representative of most of the cities in south-central Chile. We therefore suggest this as an adequate setting to evaluate the real effect of the environmental contamination produced by the smoke of WCRH in the reproductive system. The limited number of studies reported on the effects of this type of emission on the female reproductive system, present a challenge for the morphological sciences and also for those who make decisions that affect public health.

KEY WORDS: Air Pollution; Reproductive System; WCRH; Uterus.

\section{INTRODUCTION}

Air pollution represents a serious public health problem that massively affects the entire population. Its harmful effects on health have been reported worldwide. In the Chilean Academy of Medicine in its Declaration on Air Pollution (Oyarzún \& Valdivia, 2012) points out, among other things, that the damage caused by atmospheric pollutants is not limited only to the lungs, which are its gateway, but also compromises the entire body (Pino et al., 2015). However, there is also no scientific evidence regarding the identification of the most harmful exposure period, and its relation to the stages of pregnancy. Furthermore there is no information on what specific particles would play a harmful role in some of the physiological processes involved during gestation, or the mechanism by which air pollution influences the development of the embryo/fetus. Regarding air pollution and its effects on the reproductive system, different hypotheses have been put forward: i) it may cause placental inflammation, ii) it would affect placental development mainly in structures and mechanisms that are sensitive to oxygen tension and its exchange and iii) it would affect trophoblast development as a result of a deficit in placental vascularization (Veras et al., 2009). The possibility that maternal exposure to different environmental contaminants, even before pregnancy, may affect reproduction has already been noted in occupational epidemiology literature (Silbergeld \& Patrick, 2005; Veras et al., 2009). In addition, it is known that exposure to adverse environmental conditions during pregnancy can affect the health of adult offspring, in a phenomenon known as fetal programming. Any abnormalities in the placenta are a potential culprit in preterm labor, malformation or abortion. Toxic 
substances act on placental function, altering growth, production of hormones and enzymes, gas exchange, nutrients, excreta and cell differentiation. The effects are easily evidenced in models of administration or involuntary exposure to high doses of toxins; however, exposure to relatively low levels, such as those observed during atmospheric air pollution, have been poorly studied.

Air Pollution In The Center-South Of Chile. In large urban centers around the world, studies have been carried out on atmospheric air pollution and its effects (Oyarzún, 2010; Romieu et al., 2012). Main sources of emission of particulate matter (PM) and toxic substances the combustion of derived from motor vehicles and industries (Nikula et al., 1995). However, in small and medium-sized urban centers, pollution studies and their impact on health are limited. In cities of southern Chile, the annual environmental PM 2.5 concentration was measured in several cities through the National Air Quality Information System, demonstrating that it has considerably higher concentrations annually (>30 mg/ $\mathrm{m}^{3}$ ), however, differs from large urban centers where the main source of emission is wood combustion for residential heating (WCRH; Villalobos et al., 2017). Evidence shows that nearly two million people are exposed to a high risk of air pollution (Ministerio del Medio Ambiente, 2013).

Wood smoke (humidity above $25 \%$ ) produced by WCRH is a serious problem affecting South-Central Chile (below $35^{\circ} \mathrm{S}$; Sanhueza et al., 2006; Cereceda-Balic et al., 2012; Schueftan \& González, 2013; Schiappacasse et al., 2013). This is caused by excessive and widespread use of wood for heating with the use of inefficient stoves and, in homes with poor thermal insulation, as it is one of the cheapest fuels available. In recent years cities such as Rancagua, Talca, Chillán, Gran Concepción, Los Angeles, Temuco-Padre Las Casas, Osorno, Valdivia and Coyhaique have presented serious problems of atmospheric air pollution by PM. In order to reduce the concentration of PM2.5 and PM10, government authorities have shown concern in promoting the efficient use of vehicles and combustion of firewood, implementing decontamination plans or imposing restrictions on the use of wood-burning heaters. These initiatives however, have been ineffective.

Temuco-Padre Las Casas is located $670 \mathrm{kms}$ south of the capital of Chile, Santiago, $80 \mathrm{~km}$ of the Pacific Ocean and 114 meters above sea level. It has a population of approximately 260,000 inhabitants. Its economy is based on agro-industrial, forestry and consumer based services. It is considered one of the cities with the highest levels of air pollution in Latin America (Cereceda-Balic et al.). It has been declared a "Saturated zone", next to the neighboring community of Padre Las Casas, presenting high concentrations of breathable PM10 (Ministerio Secretaría General de la Presidencia, 2005). According to the latest PM10 emissions register in the city of Temuco, WCRH is the main source of contamination, accounting for $93 \%$ of emissions, which is considered by Díaz-Robles et al. (2008) as a city with "single emission source" (monosource). The negative effects of air pollution are undisputed, especially those attributed to PM. In Temuco (with 1587 annual deaths, of which $24 \%$ were due to cardiovascular and $11 \%$ to respiratory causes), there are no experimental studies that associate air pollution with health effects. Sanhueza et al. (2009), published an epidemiological study, in which they reported a strong association between PM10 and daily mortality during the period (1997-2002), in people older than 65 years, and for hospital admissions, cardiovascular diseases represented $6 \%$ and emergency room visits for acute respiratory infections represented $28 \%$.

Air Pollution And The Reproductive System. In general, the evidence on the effects of PM on health comes from epidemiological studies and to a lesser extent from studies of controlled exposure in human, or toxicological in animals (WHO, 2014). Although most of them describe cardiac and respiratory problems (Vinitketkumnuen et al., 2002; Sanhueza et al.; Cakmak et al., 2007) an association between exposure to air pollution and reproductive problems has been suggested. Regarding the period and level of exposure to air pollution, it is important to mention that: i) effects on different body systems can occur in both short and long term exposure (Katsouyanni et al., 2001) and ii) the evidence suggests that low levels of exposure can cause adverse health effects. Alterations to pregnancies which occur due to atmospheric pollution, such as: perinatal mortality, preterm birth, low birth weight, and sperm viability are parameters that have been frequently used to assess the effects of air pollution on the process of human reproduction (WHO). Studies have presented evidence suggesting an association between both variables, particularly affecting pregnancy, fertility, and fetus health (Wiebe \& Barr, 1998). The studies have shown a considerable consistency between exposure to air pollution and pregnancy alterations, particularly those related to PM exposure. Published works are mainly retrospective and prospective epidemiological studies evaluating gestation parameters and where the discussion focuses primarily on the type of pollutants and their associations, statistical methods, and systematic reviews (Díaz-Robles et al.; Frutos et al., 2015; Checa Vizcaíno et al., 2016).

Scientific evidence is limited in relation to experimental studies with laboratory animals in real environmental conditions, especially with exposure to air pollution by WCRH smoke and its effects on reproductive function. In 
Brazil, there are recorded studies, which used "exposure chambers". In these, rats were exposed to filtered and nonfiltered surrounding air. Those exposed to environmental pollution exhibited a lower number of live-born pups and an increased frequency of alterations of implantation and moreover, a decrease in the male/female ratio in those exposed to non-filtered air (Mohallem et al., 2005; Lichtenfels et al., 2007; Veras et al., 2010). In Chile, there are no data on this topic.

The biological mechanisms by which different environmental pollutants in the air affect the reproductive system - including smoke produced by combustion of firewood - are not yet understood. Also, there is no consensus with respect to which gestation period is the most critical, regarding exposure and placental function. From the epidemiological point of view, the most frequent clinical data associated with air pollution are infertility, perinatal mortality, preterm birth, low birth weight and oogenesis/ folliculogenesis alterations.

One of the causes of infertility is associated with implantation failures, hormonal disruptors or changes on the signaling systems (Wide, 1995). One of these is endocannabinoid signaling, crucial for preimplantation embryonic development, tubal transport and ultimately, implantation in the uterus. This signalization, moreover, is determinant in the regulation of the time of embryonic implantation and uterine reception. Any factor, air pollution included, that alters endocannabinoid signaling will induce failures in any of these processes. In mice, Anandamide (Narachidonoylethanolamine; endogenous endocannabinoid), an arachidonic acid derivative, is an endogenous ligand for both the brain-type (CB1-R) and splen-type (CB2-R) cannabinoid receptors, has been shown to modulate the probability of implantation in the uterine wall. Plasma anandamide (AEA) levels fluctuate throughout the menstrual cycle and in early pregnancy in a pattern suggesting its involvement in implantation and early pregnancy maintenance, through mechanisms that might involve its binding to cannabinoid receptors CB1 and CB2 (Wang \& Dey, 2006). Plasma AEA levels are maintained by the actions of the enzymes fatty acid amide hydrolase (FAAH) and Nacyl phosphatidylethanolamine-phospholipase D (NAPEPLD). All of these component parts of the "endocannabinoid system'.

Evidence suggests that exposure to high concentrations of PM10 and $\mathrm{SO}_{2}$, are correlated with increases in neonatal and post-neonatal mortality rates, especially due to respiratory diseases (Bobak \& Leon, 1999). Regarding neonatal mortality, previous studies relate an increase in post-natal mortality with exposure to levels above
$12 \mathrm{~m} / \mathrm{m}^{3}$ of PM10 (Kaiser et al., 2004). With respect to postneonatal mortality, a positive association between postneonatal respiratory mortality, and the effects of air pollution on the morbidity of respiratory disease in children has been reported (Ilabaca et al., 1999). An association has been reported between post-neonatal death and the levels of PM10 in approximately 4 million babies. Also, between babies exposed to PM10 concentration and deaths due to respiratory problems and sudden infant death syndrome (Lipfert et al., 2000). In Chile, at the time of writing this review, there are no data on this topic.

Preterm birth is the leading cause of neonatal mortality and morbidity (Xu et al., 1995). There is little evidence regarding its association with the mother's exposure to air pollution during pregnancy. Studies reported a relationship between maternal exposures and relatively low concentrations of pollutants in the air with the occurrence of preterm birth: PM10 and $\mathrm{O}_{3}$ exposure during the first trimester of pregnancy and high levels of $\mathrm{SO}_{2}$ during the month of conception are associated with an increased risk of preterm birth (Lee et al., 2003; Mannes et al., 2005; Hansen et al., 2006). In Chile, there are no data on this topic.

Low birth weight is the most frequently observed effect associated with exposure to polluted air, suggesting that fetal growth and duration of gestation are affected (Maisonet et al., 2004; Gouveia et al., 2004). This data are obtained from studies conducted in large urban centers. However, the literature is currently unclear regarding the period of pregnancy that is most susceptible to exposure to polluted air; the information is controversial: it seems that exposure to $\mathrm{PM} 10, \mathrm{SO}_{2}$ and $\mathrm{NO}_{2}$ at any stage of gestation involves a greater risk (Liu et al., 2003), however, the evidence is limited. Regarding parental exposure prior to conception, epidemiological data suggest that certain environmental pollutants may affect gestation and fetal development (Silbergeld \& Patrick). However, experimental studies that confirm this association are limited. Again there are no data available in Chile on this topic.

Studies regarding air pollution and effects on the ovary are limited. In Spain, García-Pérez et al. (2015) evaluated the association between ovarian cancer and proximity to industries, and reported results suggesting that residing in the vicinity of industries and the air pollution that these produce may be a risk for mortality from ovarian cancer.

Mechanisms involved. Although the mechanisms are unclear, there is prior information suggesting how air pollution affects reproductive processes outcomes. Studies suggest that the decrease in $\mathrm{O}_{2}$ concentration in tension is 
the main factor capable of causing alterations in both the placenta (Behrman, 1992; Veras et al., 2008). This decrease in oxygen availability may be due to increased blood viscosity, or to an increase in the concentration of carboxyhemoglobin and methemoglobin. Pregnant women exposed to increased concentrations of $\mathrm{SO}_{2}$ and $\mathrm{NO}$ show an increase in lactate dehydrogenase ( $\mathrm{LDH})$ activity in the placenta, which would indicate that the anaerobic route is metabolizing glucose, since the $\mathrm{O}_{2}$ tension must be decreased (Kaiglová et al., 2001). Hypoxia has been associated with placental fibrosis, increase in the synthesis of fibronectin, collagen IV and collagen I versus a reduction of oxygen tension. It is believed that the contamination affects its dynamics causing placental insufficiency (Kaufmann et al., 2004). The relationship between air pollution and oxidative stress is well known. In certain gestational pathologies (diabetes, pre-eclampsia, intrauterine growth restriction or early fetal loss), oxidative stress levels are higher. These elevated levels may then affect placental function, since ROS production has marked effects on trophoblast proliferation, angiogenesis, incr $n_{i}$ s, such as endothelin. Scalera et al. (2002) demonstrated that increased levels of endothelin-1 are associated with the high level of lipid peroxides.

In general, these mechanisms act synergistically with each other. Some authors (Pope et al., 1995; Shaw \& Gold, 1998; Mohorovic, 2004) consider that the inhalation of toxic substances (from coal combustion) is decisive in the appearance of premature births and low birth weight babies due to a permanent oxidative stress, presented: hypoxia and inhibition of the antioxidant system and the imbalance in ROS production. Inhaled carbon monoxide also binds strongly to hemoglobin to form carboxyhemoglobin $(\mathrm{COHb})$, preventing the transport of oxygen and can also bind to cytochrome oxidase, resulting in a decrease in oxygen uptake by cells. The normal development of the placenta is largely governed by appropriate oxygen tension.

Previous studies have shown that air pollution impacts heart health and affects breathing and lung function, but less is known about whether air pollution affects the reproductive processes. Most of the studies cited in this research proposal describe the health effects or reproductive system produced by air pollution; however, the majority have been conducted in environments whose main source of PM emission is fuel combustion by motor vehicles and industries, not considering the effects produced by the WCRH smoke. Scientific evidence regarding ovarian, uterine and placental morphofunction and its association with air pollution by the WCRH smoke is extremely limited.

New research initiatives will provide morphological responses to a relevant and global public health problem and provide background to develop new actions aimed at mitigating the possible harmful effects on the reproductive health of the population. In Chile, progress has been made to combat environmental pollution, such as the reinforcement of environmental agencies, advances in public and private transportation, the development of urban highways, the installation and modernization of monitoring networks, control of emission sources, and the application of regulations that aim to reduce emissions; nonetheless, according to the Chilean Academy of Medicine (Oyarzún \& Valdivia), these efforts have been insufficient. One of the challenges is to intensify actions such as promoting research in this area.

SALINAS, P. Efectos sobre el Sistema Reproductivo Femenino de Contaminación del Aire Producido por el Uso de la Combustión de Madera para Calefacción Residencial: Retos y Perspectivas de los Estudios Morfológicos. Int. J. Morphol., 36(2):623-628, 2018.

RESUMEN: Estudios previos han demostrado que la polución del aire afecta la función cardio-respiratoria, pero el rol que tiene ésta respecto a los procesos reproductivos es desconocida. Existen escasos antecedentes experimentales sobre sus efectos sobre la morfo-función en el sistema reproductivo. El uso de la combustión de madera para calefacción residencial (WCRH) en las ciudades del centro-sur de Chile ha aumentado significativamente. Como resultado, se ha convertido en una fuente de emisión importante de material particulado en suspensión (PM) en el aire ambiental. La posible asociación entre exposición a PM y problemas reproductivos ha sido sugerida solo en base a estudios epidemiológicos, la mayoría de ellos realizados en ambientes donde la principal fuente de emisión de PM es la combustión del petróleo por vehículos motorizados e industrias, ignorando los efectos producidos por el humo de WCRH. Por ejemplo, en la ciudad de Temuco-Padre Las Casas, Chile, el $93 \%$ de las emisiones de PM corresponden al humo de WCRH, por lo tanto, es considerada como un área urbana con una fuente de emisión de PM única y los factores que contribuyen a este tipo de contaminación son razonablemente representativos a la mayoría de las ciudades en el centro-sur de Chile, lo que permite sugerirla como un ambiente adecuado para evaluar el efecto de la contaminación ambiental producida por el humo de la WCRH en el sistema reproductivo. Los escasos estudios reportados sobre los efectos de este tipo de emisión sobre el sistema reproductivo femenino constituyen un desafío no tan solo para las ciencias morfológicas, sino que además, para quienes toman decisiones que afectan la salud publica.

PALABRAS CLAVE: Polución del aire; Sistema reproductivo; WCRH; Útero.

\section{REFERENCES}

Behrman, R. E. Nelson Textbook of Pediatrics. 14 th $^{\text {t }}$ ed. Philadelphia, Saunders, 1992.

Bobak, M. \& Leon, D. A. The effect of air pollution on infant mortality appears specific for respiratory causes in the postneonatal period. Epidemiology, 10(6):666-70, 1999. 
Cakmak, S.; Dales, R. E. \& Vidal, C. B. Air pollution and mortality in Chile: susceptibility among the elderly. Environ. Health Perspect., 115(4):524-7, 2007.

Cereceda-Balic, F.; Fadic, X.; Llanos, A. L.; Dominguez, A. M.; Guevara, J. L.; Vidal, V.; Díaz-Robles, L. A.; Schiappacasse, L. N. \& Etcharren, P. Obtaining polycyclic aromatic hydrocarbon concentration ratios and molecular markers for residential wood combustion: Temuco, a case study. J. Air Waste Manag. Assoc., 62(1):44-51, 2012.

Checa Vizcaíno, M. A.; González-Comadran, M. \& Jacquemin, B. Outdoor air pollution and human infertility: a systematic review. Fertil. Steril., 106(4):897-904, 2016.

Delfino, R. J.; Sioutas, C. \& Malik, S. Potential role of ultrafine particles in associations between airborne particle mass and cardiovascular health. Environ. Health Perspect., 113(8):934-46, 2005.

Díaz-Robles, L. A.; Ortega, J. C.; Fu, J. S.; Reed, G. D.; Chow, J. C.; Watson, J. G. \& Moncada-Herrera, J. A. A hybrid ARIMA and artificial neural networks model to forecast particulate matter in urban areas: The case of Temuco, Chile. Atmos. Environ., 42(35):8331-40, 2008.

Frutos, V.; González-Comadrán, M.; Solà, I.; Jacquemin, B.; Carreras, R. \& Checa Vizcaíno, M. A. Impact of air pollution on fertility: a systematic review. Gynecol. Endocrinol., 31(1):7-13, 2015.

García-Pérez, J.; Lope, V.; López-Abente, G.; González-Sánchez, M. \& Fernández-Navarro, P. Ovarian cancer mortality and industrial pollution. Environ. Pollut., 205:103-10, 2015.

Gouveia, N.; Bremner, S. A. \& Novaes, H. M. Association between ambient air pollution and birth weight in São Paulo, Brazil. J. Epidemiol. Community Health, 58(1):11-7, 2004.

Hansen, C.; Neller, A.; Williams, G. \& Simpson, R. Maternal exposure to low levels of ambient air pollution and preterm birth in Brisbane, Australia. B. J. O. G., 113(8):935-41, 2006.

Ilabaca, M.; Olaeta, I.; Campos, E.; Villaire, J.; Tellez-Rojo, M. M. \& Romieu, I. Association between levels of fine particulate and emergency visits for pneumonia and other respiratory illnesses among children in Santiago, Chile. J. Air Waste Manag. Assoc., 49(9 Spec. No.):154-63, 1999.

Kaiglová, A.; Reichrtová, E.; Adamcáková, A. \& Wsólová, L. Lactate dehydrogenase activity in human placenta following exposure to environmental pollutants. Physiol. Res., 50(5):525-8, 2001.

Kaiser, R.; Romieu, I.; Medina, S.; Schwartz, J.; Krzyzanowski, M. \& Künzli, N. Air pollution attributable postneonatal infant mortality in U.S. metropolitan areas: a risk assessment study. Environ. Health, 3(1):4, 2004.

Katsouyanni, K.; Touloumi, G.; Samoli, E.; Gryparis, A.; Le Tertre, A.; Monopolis, Y.; Rossi, G.; Zmirou, D.; Ballester, F.; Boumghar, A.; Anderson, HR.; Wojtyniak, B.; Paldy, A.; Braunstein, R.; Pekkanen, J.; Schindler, C. \& Schwartz, J. Confounding and effect modification in the short-term effects of ambient particles on total mortality: results from 29 European cities within the APHEA2 project. Epidemiology, 12(5):521-31, 2001.

Kaufmann, P.; Mayhew, T. M. \& Charnock-Jones, D. S. Aspects of human fetoplacental vasculogenesis and angiogenesis. II. Changes during normal pregnancy. Placenta, 25(2-3):114-26, 2004.

Lee, B. E.; Ha, E. H.; Park, H. S.; Kim, Y. J.; Hong, Y. C.; Kim, H. \& Lee, J. T. Exposure to air pollution during different gestational phases contributes to risks of low birth weight. Hum. Reprod., 18(3):638-43, 2003.

Lichtenfels, A. J.; Gomes, J. B.; Pieri, P. C.; El Khouri Miraglia, S. G.; Hallak, J. \& Saldiva, P. H. Increased levels of air pollution and a decrease in the human and mouse male-to-female ratio in São Paulo, Brazil. Fertil. Steril., 87(1):230-2, 2007.

Lipfert, F. W.; Zhang, J. \& Wyzga, R. E. Infant mortality and air pollution: a comprehensive analysis of U.S. data for 1990. J. Air Waste Manag. Assoc., 50(8):1350-66, 2000.

Liu, S.; Krewski, D.; Shi, Y.; Chen, Y. \& Burnett, R. T. Association between gaseous ambient air pollutants and adverse pregnancy outcomes in Vancouver, Canada. Environ. Health Perspect., 111(14):1773-8, 2003.
Maisonet, M.; Correa, A.; Misra, D. \& Jaakkola, J. J. A review of the literature on the effects of ambient air pollution on fetal growth. Environ. Res., 95(1):106-15, 2004.

Mannes, T.; Jalaludin, B.; Morgan, G.; Lincoln, D.; Sheppeard, V. \& Corbett, S. Impact of ambient air pollution on birth weight in Sydney, Australia. Occup. Environ. Med., 62(8):524-30, 2005.

Mildenberger, E.; Siegel, G. \& Versmold, H. T. Oxygen-dependent regulation of membrane potential and vascular tone of human umbilical vein. Am. J. Obstet. Gynecol., 181(3):696-700, 1999.

Ministerio del Medio Ambiente. Primer Reporte del Estado del Medio Ambiente. Santiago de Chile, Ministerio del Medio Ambiente, 2013. Available from: http://sinia.mma.gob.cl/wp-content/uploads/2017/08/ M2500MIN2013.pdf

Ministerio Secretaría General de la Presidencia. D.S. No. 35/2005-Declara Zona Saturada por Material Particulado Respirable MP10, como Concentración de 24 Horas, a las Comunas de Temuco y Padre Las Casas. (DO 11.05.2005). Santiago de Chile, Biblioteca del Congreso Nacional de Chile, 2005. Available from: https://www.leychile.cl/ $\mathrm{N} ? \mathrm{i}=237789 \& \mathrm{f}=2005-05-11 \& \mathrm{p}=$

Mohallem, S. V.; de Araújo Lobo, D. J.; Pesquero, C. R.; Assunção, J. V.; de Andre, P. A.; Saldiva, P. H. \& Dolhnikoff, M. Decreased fertility in mice exposed to environmental air pollution in the city of São Paulo. Environ. Res., 98(2):196-202, 2005.

Mohorovic, L. First two months of pregnancy critical time for preterm delivery and low birthweight caused by adverse effects of coal combustion toxics. Early Hum. Dev., 80(2):115-23, 2004.

Myatt, L. \& Cui, X. Oxidative stress in the placenta. Histochem. Cell Biol., 122(4):369-82, 2004.

Nikula, K. J.; Snipes, M. B.; Barr, E. B.; Griffith, W. C.; Henderson, R. F. \& Mauderly, J. L. Comparative pulmonary toxicities and carcinogenicities of chronically inhaled diesel exhaust and carbon black in F344 rats. Fundam. Appl. Toxicol., 25(1):80-94, 1995.

Oyarzún, G. M. \& Valdivia, C. G. Contaminación atmosférica. Declaración de la Academia de Medicina, Instituto de Chile. Rev. Chil. Enf. Respir., 28(3):171-3, 2012.

Oyarzún, G. M. Air pollution an its effects on health. Rev. Chil. Enferm. Respir., 26(1):16-25, 2010.

Pino, P; Iglesias, V.; Garreaud, R.; Cortés, S.; Canals, M.; Folch, W.; Burgos, S.; Levy, K.; Naeher, L. P. \& Steenland, K. Ann Glob Health. Chile confronts its environmental health future after 25 years of accelerated growth. Ann. Glob. Health, 81(3):354-67, 2015.

Pope, C. A. 3rd; Thun, M. J.; Namboodiri, M. M.; Dockery, D. W.; Evans, J. S.; Speizer, F. E. \& Heath, C. W. Jr. Particulate air pollution as a predictorof mortality in a prospective study of U.S. adults. Am. J. Respir. Crit. Care Med., 151(3 Pt. 1):669-74, 1995.

Romieu, I.; Gouveia, N.; Cifuentes, L. A.; de Leon, A. P.; Junger, W.; Vera, J.; Strappa, V.; Hurtado-Díaz, M.; Miranda-Soberanis, V.; Rojas-Bracho, L.;Carbajal-Arroyo, L.; Tzintzun-Cervantes, G. \& HEI Health Review Committee. Multicity study of air pollution and mortality in Latin America (the ESCALA study). Res. Rep. Health Eff. Inst., (171):5-86, 2012.

Sanhueza, P. A.; Torreblanca, M. A.; Diaz-Robles, L. A.; Schiappacasse, L. N.; Silva, M. P. \& Astete, T. D. Particulate air pollution and health effects for cardiovascular and respiratory causes in Temuco, Chile: a wood-smoke-polluted urban area. J. Air Waste Manag. Assoc., 59(12):1481-8, 2009.

Sanhueza, P.; Vargas, C. \& Mellado, P. Impact of air pollution by fine particulate matter (PM10) on daily mortality in Temuco, Chile. Rev. Med. Chile, 134(6):754-61, 2006.

Scalera, F.; Dittrich, R.; Beckmann, M. W. \& Beinder, E. Effect of endothelin-1 on intracellular glutathione and lipid peroxide availability and on the secretion of vasoactive substances by human umbilical vein endothelial cells. Eur. J. Clin. Invest., 32(8):556-62, 2002.

Schiappacasse, P. N.; Díaz-Robles, L. A.; Cereceda-Balic, F. \& Silva, S. P. Health impacts in South-central Chile due to misuse of wood-burning stoves. Electron. J. Energy Environ., 1(3):65-71, 2013. 
SALINAS, P. Effects on the female reproductive system of air pollution produced by the use of wood combustion for residential heating: Challenges and perspectives of morphological studies. Int. J. Morphol., 36(2):623-628, 2018.

Schueftan, A. \& González, A. D. Reduction of firewood consumption by households in south-central Chile associated with energy efficiency programs. Energy Policy, 63:823-32, 2013.

Shaw, G. M. \& Gold, E. B. Methodological considerations in the study of parental occupational exposures and congenital malformations in offspring. Scand. J. Work. Environ. Health, 14(6):344-55, 1988.

Silbergeld, E. K. \& Patrick, T. E. Environmental exposures, toxicologic mechanisms, and adverse pregnancy outcomes. Am. J. Obstet. Gynecol., 192(5 Suppl.):S11-21, 2005.

Veras, M. M.; Caldini, E. G.; Dolhnikoff, M. \& Saldiva, P. H. Air pollution and effects on reproductive-system functions globally with particular emphasis on the Brazilian population. J. Toxicol. Environ. Health $B$ Crit. Rev., 13(1):1-15, 2010.

Veras, M. M.; Damaceno-Rodrigues, N. R.; Caldini, E. G.; Maciel Ribeiro, A. A.; Mayhew, T. M.; Saldiva, P. H. \& Dolhnikoff, M. Particulate urban airpollution affects the functional morphology of mouse placenta. Biol. Reprod., 79(3):578-84, 2008.

Veras, M. M.; Damaceno-Rodrigues, N. R.; Guimarães Silva, R. M.; Scoriza, J. N.; Saldiva, P. H.; Caldini, E. G. \& Dolhnikoff, M. Chronic exposure to fine particulate matter emitted by traffic affects reproductive and fetal outcomes in mice. Environ. Res., 109(5):536-43, 2009.

Villalobos, A. M.; Barraza, F.; Jorquera, H. \& Schauer, J. J. Wood burning pollution in southern Chile: PM2.5 source apportionment using CMB and molecular markers. Environ. Pollut., 225:514-23, 2017.

Vinitketkumnuen, U.; Kalayanamitra, K.; Chewonarin, T. \& Kamens, R. Particulate matter, PM10 e PM2.5 levels, and airborne mutagenicity in Chiang Mai, Thailand. Mutat. Res., 519(1-2):121-31, 2002.

Wang, H. \& Dey, S. K. Roadmap to embryo implantation: clues from mouse models. Nat. Rev. Genet., 7(3):185-99, 2006.

Wide, M. Lead exposure on critical days of fetal life affects fertility in the female mouse. Teratology, 32(3):375-80, 1995.

Wiebe, J. P. \& Barr, K. J. Effect of prenatal and neonatal exposure to lead on the affinity and number of estradiol receptors in the uterus. J. Toxicol. Environ. Health, 24(4):451-60, 1998.

World Health Organization (WHO). Ambient (Outdoor) Air Pollution DataBase, by Country and City. Ambient (Outdoor) Air Pollution in Cities Database. Geneva, World Health Organization, 2014.

Xu, X.; Ding, H. \& Wang, X. Acute effects of total suspended particles and sulfur dioxides on preterm delivery: a community-based cohort study. Arch. Environ. Health, 50(6):407-15, 1995.
Corresponding author:

Paulo Salinas

Institute of Biology Faculty of Sciences

Pontificia Universidad Católica de Valparaíso

CHILE

\section{E-mail: paulo.salinas@pucv.cl}

Received: 09-02-2018

Accepted: 07-03-2018 